\title{
Analisis Perputaran Persediaan Dalam Menilai Return On Asset (ROA) Pada PT. Kalbe Farma, Tbk Periode 2015 - 2019
}

\author{
Edison Hamid \\ Sekolah Tinggi Ilmu Ekonomi Tribuana \\ edisonvgh@yahoo.com
}

\begin{abstract}
Abstrac
This study aims to determine how inventory turnover is in assessing Return On Asset. The research object, namely PT. Kalbe Farma, Tbk, which is taken from the financial reports for the period 20152019. This study used a qualitative method consisting of two variables, namely inventory cycle as the independent variable and return on asset the dependent variable. The data analysis method used in this research is inventory turnover analysis and return on asset analysis. The test results show that the average inventory turnover of 3.15 per year as a whole is categorized as good, when viewed from the general standard or the industry average which is above 2.5 times. For the average return on asset, it shows that return on asset is included in the very good criteria because it has reached the company standard. Then from the comparison of inventory turnover and return on assetor the last 5 years of the 2015-2019 period, the contribution of inventory turnover in assessing return on asset was $21.28 \%$ and the rest contributed to other factors not examined in this study.
\end{abstract}

Keywords: Inventory Turnover, Return On Asset

\section{Abstrak}

Penelitian ini bertujuan untuk mengetahui bagaimana perputaran persediaan dalam menilai Return On Asset. Objek penelitian yaitu PT. Kalbe Farma, Tbk yang diambil dari laporan keuangan periode 2015-2019. Penelitian ini menggunakan metode kualitatif yang terdiri dari dua variabel yaitu siklus persediaan sebagai variabel bebas dan return on asset sebagai variabel terikat. Metode analisis data yang digunakan dalam penelitian ini adalah analisis perputaran persediaan dan analisis return on asset. Hasil pengujian menunjukkan bahwa rata-rata perputaran persediaan 3,15 per tahun secara keseluruhan dikategorikan baik, jika dilihat dari standar umum atau rata-rata industri yang berada di atas 2,5 kali. Untuk ratarata return on asset menunjukkan bahwa return on asset termasuk dalam kriteria sangat baik karena telah mencapai standar perusahaan. Kemudian dari perbandingan perputaran persediaan dan return on assetor 5 tahun terakhir periode 2015-2019, kontribusi perputaran persediaan dalam menilai return on asset adalah 21,28\% dan sisanya berkontribusi pada faktor lain yang tidak diteliti dalam penelitian ini.

Kata kunci: Perputaran Persediaan, ROA

\section{PENDAHULUAN}

Setiap pemilik usaha menginginkan bisnis yang dibangunnya mendapatkan profit dari modal yang dikeluarkan untuk kelangsungan hidup usaha. Kelangsungan hidup usaha selalu dihubungkan dengan seorang manajemen dalam mengelola perusahaan baik dari faktor keuangan maupun non-keuangan.

Untuk melihat keberhasilan dalam mengelola keuangan perusahaan dapat dilihat dari laporan keuangan, laporan keuangan merupakan media informasi yang digunakan oleh perusahaan untuk melaporkan keadaan posisi keuangan atau 
aktivitas perusahaan kepada pihak-pihak yang berkepentingan.

Menurut Prihadi (2010:8), "Laporan keuangan adalah hasil dari kegiatan pencatatan seluruh transaksi keuangan di perusahaan". Kemudian menurut Ikatan Akuntan Indonesia dalam Septiana (2019:2), "Laporan keuangan adalah struktur yang menyajikan posisi keuangan dan kinerja keuangan dalam sebuah entitas".

Dalam laporan keuangan laba/rugi perusahaan merupakan hal utama yang diperhatikan oleh para calon investor untuk memastikan bahwa investasi yang dilakukan layak dan memperoleh hasil sesuai yang diharapkan. Untuk mengetahui kemampuan perusahaan dalam menghasilkan laba dapat dilihat dari tingkat profitabiltas yang dimiliki oleh perusahaan.

Menurut Hery (2015:192), "Profitabilitas merupakan rasio yang menggambarkan kemampuan perusahaan dalam menghasilkan laba melalui semua kemampuan dan sumber daya yang dimilikinya, yaitu yang berasal dari kegiatan penjualan, penggunaan asset, maupun penggunaan modal". Profitabilitas merupakan tolak ukur dalam menentukan berhasil atau tidaknya suatu usaha. Untuk dapat mengetahui perputaran kas suatu perusahaan dapat diketahui dengan membandingkan penjualan bersih dengan jumlah kas rata-rata perusahaan (Marpaung, 2021). Untuk mengetahui profitabilitas suatu perusahaan dapat diketahui dengan membandingkan laba bersih yang diperoleh dengan total asset yang terdapat pada laporan keuangan. Ada beberapa jenis rasio yang digunakan untuk mengukur profitabilitas, salah satunya yaitu rasio Return On Invesment (ROA) yang digunakan dalam penelitian ini.

Adapun formula yang digunakan untuk menentukan rasio retur on asset (ROA), menurut Kasmir (2014:201) adalah :

$$
\begin{aligned}
& \text { ROA }=\frac{\text { Laba Bersih Setelah Pajak }}{\text { Total Aset }} \times 100 \% \\
& \text { Menurut Hanafi dan } \quad \text { Halim } \\
& (2018: 81) \text {, "Return On Assets }
\end{aligned}
$$
adalah rasio yang mengukur kemampuan perusahaan menghasilkan laba bersih berdasarkan tingkat assets yang tertentu". Robinson dan Chi Hwee Tan (2014:49) menyatakan bahwa, "Return On Assets (ROA) adalah ukuran profitabilitas dimana angka yang lebih tinggi lebih disukai dari pada angka yang lebih rendah. Biasanya dihitung sebagai laba bersih dibagi dengan total asset”. Rasio Return On Assets (ROA) dapat membantu manajemen atau investor untuk melihat seberapa baiknya kinerja keuangan. Semakin tinggi rasio Return On Asset menandakan semakin baik kinerja perusahaan dalam 
menghasilkan laba bersih, begitupun sebaliknya.

Dalam menghasilkan laba tentunya tidak terlepas dari ketersediaan barang dagangan yang di miliki oleh perusahaan, yang disebut dengan persediaan. Persediaan dapat didefinisikan sebagai aset berwujud yang diperoleh perusahaan untuk dijual kembali dalam kegiatan normal perusahaan dan yang diperoleh untuk diproses lebih dulu dan dijual, Purwaji.dkk (2018:119). Persediaan juga bisa dikatakan harta yang disimpan dan menganggur atau menunggu untuk digunakan atau dijual. Persediaan dilaporkan sebagai aktiva lancar dalam neraca sesuai dengan tingkat likuiditasnya.

Untuk mempercepat pengembalian aktiva melalui penjualan maka perlu adanya Perputaran Persediaan yang baik. Menurut Kasmir (2018:180), "Perputaran Sediaan merupakan rasio yang digunakan untuk mengukur berapa kali dana yang di tanam pada persediaan (Inventory) ini berputar dalam satu periode". Dapat diartikan bahwa Perputaran Persediaan merupakan rasio yang menunjukkan berapa kali jumlah persediaan berganti dalam satu tahun. Semakin tinggi perputaran persediaan maka akan meningkatkan laba, demikian pula sebaliknya.

$\begin{array}{clr}\text { Menurut } & \text { Harahap } & \text { (2011:308), } \\ \text { "Perputaran } & \text { Persediaan } & \text { adalah }\end{array}$
menunjukkan seberapa cepat perputaran persediaan dalam siklus produksi normal, semakin cepat perputaran persediaan maka penjualan berjalan cepat, dan perusahaan dianggap baik dalam usaha memperoleh laba“.

Berdasarkan beberapa pendapat para ahli dapat disimpulkan bahwa perputaran persediaan merupakan rasio yang menunjukkan tingkat efisiensi pengelolaan persediaan dilihat dari seberapa cepat persediaan terjual dalam satu periode sehingga dapat dinilai baik dalam memperolah laba perusahaan. Rasio perputaran persediaan sering menjadi acuam departemen produksi dan penjualan melalui rasio ini mereka dapat bekerja selaras sehingga produk yang diproduksi tidak berlebihan. Perputaran persediaan dalam kegiatan pendistribusian perlu memperhitungkan nilai jangka waktu hari yang dibutuhkan dalam pengeluaran barang atau produk dari gudang perusahaan.

Menurut James dalam Kasmir (2018:180) Perputaran Persediaan dapat diukur dengan menggunakan rumus berikut:

\begin{tabular}{|l|}
\hline $\begin{array}{l}\text { Inventory Turnover }= \\
\text { Harga Pokok Penjualan }\end{array}$ \\
Persediaan
\end{tabular}


Perputaran persediaan, yang tinggi, maka semakin tinggi kesempatan untuk memproleh laba bagi perusahaan. sebaliknya, semakin lambat perputaran persediaan maka semakin kecil kesempatan untuk meproleh laba. Jadi perputaran persediaan dapat mempengaruhi tingkat laba sehinga dapat meningkatkan Return On Assets (ROA) dalam satu periode akuntansi.

Berdasarkan uraian di atas maka hipotesis penelitian dalam penelitian ini adalah:

"Diduga Perputaran Persediaan dapat menilai Return On Assets (ROA) ”.

\section{METODOLOGI PENELITIAN}

Metode yang digunakan dalam penelitian ini yaitu metode kualitatif dengan pendekatan deskriptif. Menurut Sugiarto (2015:8), Penelitian kualitatif adalah jenis penelitian yang temuantemuannya tidak diperoleh melalui prosedur statistik atau bentuk hitungan lainnya dan bertujuan mengungkapkan gejala secara holistik-kontekstual melalui pengumpulan data dari data alami dengan memanfaatkan diri peneliti sebagai instrumen kunci. Penelitian kualitatif bersifat deskriptif dan cenderung menggunakan analisis dengan pendekatan induktif.

\section{Sumber Data}

Data merupakan kumpulan angkaangka yang akan diolah menjadi sebuah informasi yang dapat digunakan salam menggambarkan sebuah penelitian. Sumber data dalam penelitian ini diperoleh dari laporan keuangan PT. Kalbe Farma Tbk, yang telah dipublikasikan di Bursa Efek Indonesia pada periode 2015 - 2019.

\section{Teknik Pengumpulan Data}

Data yang dikumpulkan dalam penelitian ini adalah data sekunder. Menurut Wibisono (2013:119), data sekunder adalah data uang didapat dan disimpan oleh orang lain yang biasanya merupakan data masa lalu atau hitorikal. Teknik pengumpulan data yang digunakan dalam penelitian ini adalah studi dokumentasi, studi kepustakaan.

Dokumen merupakan catatan peristiwa yang sudah berlalu, Sugiyono (2019:114). Dokumentasi dilakukan dengan cara mengumpulkan sumbersumber data documenter seperti histori, profil, dan laporan tahunan perusahaan. pengumpulan data diperoleh dari media internet dengan cara mengunduh informasi mengenai laporan keuangan yang dibutuhkan dalam penelitian melalui situs www.idx.co.id

Studi kepustakaan dilakukan dengan cara mengumpulkan data yang bersifat teoritis mengenai permasalahan yang 
berkaitan dengan penelitian dan menunjang kelengkapan data dengan menggunakan literature pustaka seperti buku-buku literature, skripsi, jurnal dan sumber-sumber lainnya yang sehubungan dengan penelitian.

\section{Teknik Analisis Data}

Menurut James dalam Kasmir (2018:180) menghitung perputaran persediaan adalah dengan rumus berikut:

Perputaran Persediaan $=$ $\frac{\text { Harga Pokok Penjualan }}{\text { Persediaan }}$... kali

Sumber : Kasmir (2018:180)

Dari pengukuran rasio dapat dilihat kondisi posisi perusahaan dengan cara membandingkan antara hasil perhitungan variabel perputaran persediaan dengan rata-rata industry dan hasil tersebut diterjemahkan kedalam kriteria penilaian standar rata-rata industri. Menurut Lukviarman (2016:36), perputaran persediaan dikatakan sangat baik jika nilainya $>3,4$ kali. Untuk melihat nilai perputaran persediaan dapat dilihat sebagai berikut:

Tabel. 2.1

\section{Standar Industri Perputaran} Persediaan

\begin{tabular}{|c|c|}
\hline Standar Industri & Kriteria \\
\hline$>3,4$ kali & Sangat Baik \\
\hline $2,5-3,4$ kali & Baik \\
\hline $2-2,4$ kali & Cukup Baik \\
\hline$<2$ kali & Kurang Baik \\
\hline
\end{tabular}

Sumber: Lukviarman, (2016:36)

\section{Analisis Return On Assets (ROA)}

Adapun formula yang digunakan untuk menentukan rasio retur on asset (ROA), menurut Kasmir (2014:201) adalah :

$$
\begin{aligned}
\mathrm{ROA}= & \frac{\text { Laba Bersih Setelah Pajak }}{\text { Total Aset }} \times 100 \% \\
& \text { Return On Assets (ROA) merupakan }
\end{aligned}
$$
rasio yang mampu menunjukkan keberhasilan perusahaan menghasilkan keuntungan pada masa lalu untuk kemudian diproyeksikan dimasa yang akan datang. Rasio ini juga memberikan ukuran tingkat efektivitas manajemen suatu perusahaan. Dari pengukuran rasio dapat dilihat kondisi posisi perusahaan dengan cara membandingkan antara rata-rata industri dengan hasil perhitungan variabel Return On Assets (ROA), dan hasil tersebut diterjemahkan kedalam kriteria penilaian standar rata-rata industri.

Menurut Lukviarman (2016:55), rasio ini bisa dikatakan baik jika nilainya mencapai 5,98 \%. Untuk dapat menentukan standar perhitungan 
profitabilitas (return on asset) dapat dilihat sebagai berikut:

Tabel 2.2

\section{Standar Industri Return On Asset}

\begin{tabular}{|c|c|}
\hline Standar & Kriteria \\
\hline$>5,98$ & Sangat Baik \\
\hline $4,00 \%-5,98 \%$ & Baik \\
\hline $2,50 \%-3,98 \%$ & Cukup Baik \\
\hline $1,50 \%-2,49 \%$ & Kurang Baik \\
\hline$<1,50 \%$ & Buruk \\
\hline
\end{tabular}

Sumber: Lukviarman (2016:55)

Dari hasil pembobotan masingmasing variabel lalu dibandingkan dalam hal ini bobot perputaran persediaan dibandingkan dengan bobot Return On asset maka akan mendapatkan besarnya kontribusi perputaran persediaan dalam menilai Return On asset (ROA) lalu diambil kesimpulan.

\section{Definisi Operasional Variabel}

Menurut Sugiyono (2019:68), Variable adalah suatu atribut atau sifat atau nilai dari orang, objek atau kegiatan yang mempunyai variable tertentu yang ditetapkan oleh peneliti untuk dipelajari dan kemudian ditarik kesimpulannya, dalam penelitian ini ada 2 variabel yaitu:

\section{Variabel Independen (Variabel Bebas)}

Variable independen yang digunakan dalam penelitian ini adalah Peputaran Persediaan (Invetory Turnover), yang di notasikan dengan X. Perputaran Persediaan adalah suatu ukuran yang menunjukkan berapa kali persediaan telah berputar menjadi kas dalam suatu periode.

\section{Variabel Dependen (Variabel Terikat)}

Variable dependen (terikat) yang digunakan dalam penelitian ini adalah Return On Assets (ROA), yang dinotasikan dengan Y. Return On Assets adalah pendekatan yang digunakan untuk mengukur tingkat pengembalian aset.

\section{Indikator Variabel}

Perputaran Persediaan digunakan untuk mengukur berapa lama waktu yang dibutuhkan perusahaan untuk menjual persediaannya. Rasio ini mengukur tingkat efisiensi perusahaan dalam kegiatan operasional dengan menggunakan besarnya harga pokok penjualan dan persediaan yang dimiliki perusahaan. Indikator yang digunakan untuk perputaran persediaan yaitu : Harga pokok penjualan dan rata-rata persediaan.

\section{Return On Assets merupakan}

rasio yang mengukur kemampuan perusahaan dalam menghasilkan laba yang digunakan sebagai tolak ukur pengambilan keputusan dimasa yang akan datang. Berdasarkan pemikiran diatas maka indikator Return On Assets (ROA) adalah sebagai berikut Laba bersih dan total aset. 


\section{HASIL DAN PEMBAHASAN}

\section{Analisis Deskriptif}

Perputaran persediaan merupakan salah satu indikator kinerja perusahaan karena perputaran persediaan ini dapat menggambarkan keberhasilan manajemen penjualan dan aset dalam satu periode akuntansi

PT. Kalbe Farma, Tbk. adalah perusahaan industri farmasi yang menghasilkan obat-obatan, dan PT. Kalbe Farma pada 5 tahun terakhir periode 20152019, penjualan bersih terus mengalami peningkatan dari tahun ketahun begitu juga total aset, hal ini dapat dilihat dari informasi laporan keuangan yang disajikan oleh PT. Kalbe Farma Tbk, yaitu neraca dan laporan laba/rugi, laporan keuangan inilah yang menjadi sumber data yang akan dibahas dalam penelitian ini.

\section{Uji Analisis}

Perputaran Persediaan Pada PT. Kalbe Farma, Tbk.

Keberhasilan perusahaan mengatur rasio perputaran persediaannya bisa dilihat dari perusahaan yang bisa menjaga rasio perputaran persediaan agar selalu konsisten peningkatannya dari tahaun ke tahun.

Berikut ini penulis menyajikan jumlah perputaran persediaan pertahun yang terdapat pada PT. Kalbe Farma, Tbk, dalam table 3.1 yang diambil dari data keuangan periode 2015 - 2019 dalam

milyaran rupiah sebagai berikut:

Tabel 3.1

Perputaran Persediaan

PT. Kalbe Farma, Tbk.

\begin{tabular}{|c|c|c|c|c|}
\hline Tahun & $\begin{array}{c}\text { Harga Pokok } \\
\text { Penjualan } \\
\text { (b) }\end{array}$ & \begin{tabular}{|c|} 
Rata-Rata \\
Persediaan \\
(c)
\end{tabular} & $\begin{array}{c}\text { Perputa } \\
\text { ran } \\
\text { Persediaan } \\
\text { d=b/c }\end{array}$ & $\begin{array}{c}\text { Kata } \\
\text { gori }\end{array}$ \\
\hline 2015 & 9.295 & 3.046 & $3,05 \mathrm{kali}$ & Baik \\
\hline 2016 & 9.886 & 3.173 & 3,11 kali & Baik \\
\hline 2017 & 10.369 & 3.450 & 3,00 kali & Baik \\
\hline 2018 & 11.226 & 3.516 & 3,19 kali & Baik \\
\hline 2019 & 12.390 & 3.606 & 3,43 kali & $\begin{array}{c}\text { Sangat } \\
\text { Baik }\end{array}$ \\
\hline \multicolumn{3}{|c|}{ Rata-rata } & 3,15 kali & Baik \\
\hline
\end{tabular}

Sumber: Laporan Keuangan PT. Kalbe

Farma, Tbk. data diolah

Berdasarkan pada tabel 3.1 perkembangan perputaran persediaan PT. Kalbe Farma Tbk. selama 5 tahun terakhir yaitu dari tahun 2015-2019 diperoleh nilai rata-rata sebesar 3,15 kali dan cenderung menunjukkan angka perputaran yang fluktuasi. Pada tahun 2015 perputaran persediaan yang didapatkan sebesar 3,05 kali. Lalu pada tahun 2016 mengalami sedikit kenaikan menjadi 3,11 kali, hal ini dikarenakan meningkatnya rata-rata persediaan setara dengan peningkatan harga pokok penjualan. Peningkatan perputaran persediaan menandakan semakin efektifnya manajemen persediaan dalam mengelola persediaan sehingga perputaran persediaan dengan cepat kembali menjadi kas melalui penjualan. Lalu pada tahun 2017 mengalami 
penurunan menjadi 3,00 kali dikarenakan jumlah harga pokok penjualan yang tinggi sebanding dengan rata-rata persediaan yang tinggi juga. Harga pokok penjualan yang tinggi menandakan kurang efisien dalam menggunakan harga pokok penjualan, sehingga kurang memaksimalkan peputaran persediaan. Pada tahun 2018 perputaran persediaan mengalami kenaikan menjadi 3,19 kali hal ini dikarenakan menurunya nilai persedian akhir akibat dari meningkatnya penjualan pada tahun tersebut, hal ini berpengaruh kedalam perputaran persediaan. Pada tahun 2019 perputaran persediaan kembali mengalami kenaikan menjadi 3,43 kali.

Adapun katagori perputaran persedian PT. Kalbe Farma Tbk berdasarkan standar rata - rata industri pada tahun 2015 sampai 2018 ada pada posisi baik kecuali tahun 2019 masuk dalam katagori sangat baik.

Return On Asset (ROA) pada PT. Kalbe Farma, Tbk

Rasio profitabilitas (ROA) merupakan rasio untuk menilai kemampuan perusahaan dalam mencari keuntungan. Rasio ini juga memberikan ukuran tingkat efektivitas manajemen suatu perusahaan. Tingkat profitabilitas yang tinggi pada perusahaan akan meningkatkan daya saing antar perusahaan dan menandakan pertumbuhan perusahaan pada masa mendatang.

Berikut ini penulis menyajikan return on asset pertahun yang terdapat pada PT. Kalbe Farma, Tbk. dari tahun 2015-2019 dalam milyaran rupiah yang disajikan pada tabel 3.2 adalah sebagai berikut:

Tabel 3.2

Return On Asset

PT. Kalbe Farma, Tbk.

\begin{tabular}{|c|c|c|c|c|}
\hline $\begin{array}{c}\text { Tahun } \\
\text { (a) }\end{array}$ & $\begin{array}{l}\text { Laba } \\
\text { Bersih } \\
\text { (b) }\end{array}$ & $\begin{array}{c}\text { Total } \\
\text { Aktiva } \\
\text { (c) }\end{array}$ & $\begin{array}{l}\text { ROA } \\
(\%) \\
d=b / c\end{array}$ & $\begin{array}{l}\text { Katag } \\
\text { ori }\end{array}$ \\
\hline 2015 & 2.720 & 13.696 & 19,86 & $\begin{array}{c}\text { Sangat } \\
\text { Baik }\end{array}$ \\
\hline 2016 & 2.350 & 15.226 & 15,43 & $\begin{array}{c}\text { Sangat } \\
\text { Baik }\end{array}$ \\
\hline 2017 & 2.453 & 16.616 & 14,76 & $\begin{array}{c}\text { Sangat } \\
\text { Baik }\end{array}$ \\
\hline 2018 & 2.497 & 18.146 & 13,76 & $\begin{array}{c}\text { Sangat } \\
\text { Baik }\end{array}$ \\
\hline 2019 & 2.537 & 20.264 & 12,52 & $\begin{array}{c}\text { Sangat } \\
\text { Baik }\end{array}$ \\
\hline \multicolumn{3}{|c|}{$\frac{1}{\text { Rata-rata }}$} & 15,26 & $\begin{array}{c}\text { Sangat } \\
\text { Baik }\end{array}$ \\
\hline
\end{tabular}

Sumber: Laporan Keuangan PT. Kalbe

Farma, Tbk. data diolah

Dari tabel 3.2 di atas dapat dilihat bahwa return on asset (ROA) pada PT. Kalbe Farma, Tbk. dari tahun ketahun mengalami penurunan tetapi penurunan ini masih dalam katagori sangat baik. Ratarata return on asset dari tahun 2015-2019 adalah sebesar $15,26 \%$. Return on asset pada tahun 2015 sebesar 19,86\% lalu mengalami penurunan pada tahun 2016 
menjadi $15,43 \%$, hal ini dikarenakan laba bersih setelah pajak mengalami penurunan dan ini berpengaruh atas penurunan return oniasset. Pada tahun 2017 kembali mengalami penurunan menjadi $14,76 \%$ hal ini dikarenakan adanya peningkatan pada total asset. Pada tahun 2018 kembali mengalami penurunan menjadi $13,76 \%$ hal ini pun dikarenakan adanya peningkatan pada total aset pada tahun tersebut. Pada tahun 2019 juga mengalami penurunan menjadi $12,52 \%$ hal ini dikarenakan peningkatan pada total aset melebihi peningkatan laba bersih setelah pajak pada tahun 2019

\section{Pembahasan Penelitian}

Analisis perbandingan perputaran persediaan dan return on asset pada PT. Kalbe Farma, Tbk dapat dilihat dari tabel 3.3 berikut:

Tabel 3.3

\section{Perbandingan Varibel $X$ dan $Y$}

\begin{tabular}{cccc}
\hline Tahun & $\begin{array}{c}\text { Perputaran } \\
\text { Pediaan } \\
(\mathrm{X})\end{array}$ & $\begin{array}{c}\text { ROA } \\
(\mathrm{Y})\end{array}$ & Kontribusi \\
\hline 2015 & 3,05 & 19,86 & 15,35 \\
\hline 2016 & 3,11 & 15,43 & 20,15 \\
\hline 2017 & 3,00 & 14,76 & 20,32 \\
\hline 2018 & 3,19 & 13,76 & 23,18 \\
\hline 2019 & 3,43 & 12,52 & 27,44 \\
\hline & Rata-rata & 21,28 \\
\hline
\end{tabular}

Sumber: Data diolah

Diasumsikan pada tahun 2015 apabila ada perubahan 1 kali dari perputaran persediaan akan memberikan konstribusi sebesar 15,35\% untuk return on asset (ROA) Sedangkan pada tahun 2016 apabila ada perubahan $1 \mathrm{kal}$; d dari perputaran persediaan akan memberikan kontribusi sebesar $20,15 \%$ untuk return on aseet (ROA). Untuk tahun 2017 apabila ada perubahan 1 kali dari perputaran persediaan akan memberikan kontribusi sebesar $20,32 \%$ untuk return on asset (ROA). Sedangkan pada tahun 2018 apabila ada perubahan 1 kali dari perputaran persediaan akan memberikan kontribusi sebesar 23,18\% untuk return on asset (ROA). Tahun 2019 apabila ada perubahan 1 kali dari perputaran persediaan akan memberikan kontribusi sebesar $27,44 \%$ untuk return on asset (ROA).

Dari hasil analisa tersebut diatas dapat disimpulkan bahwa peningkatan perputaran, persediaan tidak selalu diikuti oleh peningkatan return on asset hal ini dapat di buktikan dari analisis perbandingan antara variabel $\mathrm{X}$ dan variabel $\mathrm{Y}$ walaupun perputaran persediaan meningkat tetapi return on asset tetap menurun. Dengan demikian perputaran persediaan dapat memberikan kontribusi rata-rata lima tahun terakhir yaitu dari tahun 2015 sampai 2019 sebesar $21,28 \%$ ini bearti bahwa perputaran persediaan dapat menilai return on asset 
sebesar $21,28 \%$ sedangkan sisanya dipengaruhi oleh faktor-faktor lain yang tidak diteliti dalam penelitian ini.

\section{KESIMPULAN}

Berdasarkan hasil analisis pada PT. Kalbe Farma, Tbk. serta berdasarkan data yang diperoleh selama lima periode yakni dari tahun 2015 -2019 maka penulis dapat ditarik kesimpulan sebagai berikut:

1. Perputaran persediaan pada PT. Kalbe Farma Tbk selama lima tahun terakhir dari periode 2015 sampai 2019 ratarata sebesar 3,15 kali hal ini masuk katagori baik bila dilihat indikator dari rata-rata industri, sedangkan untuk return on asset untuk periode yang sama rata-rata sebesar $15,26 \%$ ini menunjukkan bahwa return on asset PT. Kalbe Farma Tbk, masuk katagori sangat baik berdasarkan idikator ratarata industri

2. Perputaran persediaan dalam menilai returnt on asset berdasarkan hasil analisa data berkontribusi sebesar 21,28 sisanya dipengaruhi oleh faktorfaktor lain yang tidak di teliti dalam penelitian ini.

\section{REFERENSI}

Fahmi, (2012). Analisis Laporan Keuangan. Bandung: alfabeta.
Harahap, S. (2011). Teori Akuntansi. Jakarta: Rajawali Pers.

Hery. (2015). Analisis Kinerja Manajemen. Jakarta: PT. Grasindo. (2016). Akuntansi Sektor Jasa dan Dagang. Jakarta: PT Grasindo.

Hidayat, W. W. (2018). Dasar-dasar Analisa Laporan Keuangan. (F. Fabri, Ed.) Ponorogo, Jawa Timur, Indonesia: Uwais Inspirasi Indonesia. Retrieved Oktober 20, 2020

Irfani, A. S. (2020). Manajemen Keuangan Dan Bisnis; Teori dan Aplikasi. Jakarta: PT. Gramedia Pustaka Utama.

Kasmir. (2018). Analisis Laporan Keuangan. Depok: Rajawali Pers

Lukviarman, Niki. 2016. Corporate Govermance, Solo: PT. Era Adicitra Intermedia.

Margaretha, F. (2011). Teori dan Palikasi Manajemen Keuangan : Investasi dan sumber dana jangka pendek. Jakarta: Grasindo.

Munawir. (2014). Analisis Laporan Keuangan. Edisi kedelapan. Yogyakarta: Liberty.

Marpaung, N. N. (2021). ANALISIS

PERPUTARAN KAS DALAM MENILAI RETURN ON ASSET PADA PT. PRASIDHA ANEKA 
NIAGA, Tbk. PARAMETER, 4(2). https://doi.org/10.37751/parameter.v4 i2. 155

Prihadi, T. (2010:120). Analisis Laporan Keuangan Teori \& Aplikasi. Jakarta: PPM.

Purwaji, Agus., Wibowo dan Hexana Sri

Lestari. (2018). Pengantar Akuntansi 2. Jakarta: Salemba Empat.

R Robinson, Thomas dan Chin Hwee Tan. (2014). Asian Financial Statement Analysis:Detecting FInancial Irreguruties. New Jersey: Wiley \& Sins, Inc.
Septiana, A. (2019). Analisis Laporan Keuangan. In A. Septiana, Analisis Laporan Keuangan. Pamekasan: Duta Media Publishing.

Sugiyono. (2019). Metode Penelitian Kuantitatif Kualitatif dan $R \& D$. Bandung: Alfabeta.

Wibisono, D. (2013). Riset Bisnis. Jakarta: PT. Gramedia Pustaka Utama.

Bursa Efek Indonesia. (n.d.). Retrieved from www.idx.co.id 